\title{
Knowledge, Attitude and Behavior Related to Antibiotic Use in Community Dwellings
}

\author{
Rocci Jack Parse, ${ }^{1}$ Eva Mardiana Hidayat, ${ }^{2}$ Bachti Alisjahbana ${ }^{3}$ \\ ${ }^{1}$ Faculty of Medicine Universitas Padjadjaran, ${ }^{2}$ Department of Pharmacology and Therapy Faculty \\ of Medicine, Universitas Padjadjaran, ${ }^{3}$ Department of Internal Medicine Faculty of Medicine, \\ Universitas Padjadjaran/Dr. Hasan Sadikin General Hospital Bandung
}

\begin{abstract}
Background: Irrational antibiotic use is the major reason for insidence of antibiotic resistance. Antibiotic misuse in community is influenced by environmental and behavioral factors. Environment included community preference for purchasing antibiotics, lack of health care infrastructure, lack of general practitioner and policy in regulating antibiotic use. Behavior is influenced by lack of information in antibiotic use and unawareness of antibiotic resistancy. The aim of the study was to assess the level of knowledge, attitude and behavior regarding antibiotic use in community dwellings.

Methods: A cross sectional descriptive study was carried out to 96 respondents who were selected by a rapid survey sampling method in Cileles village Jatinangor, Sumedang, West Java, Indonesia in August 2013. Data were collected using questionnaires. The data was analyzed in the form of frequency and percentage.

Results: Out of 96 respondents, only $40.6 \%$ had good knowledge regarding antibiotic use, $12.5 \%$ of respondents were prescribed antibiotics, but in the last course did not purchased all the antibiotics prescribed by the clinician and $55.2 \%$ of respondents did not complete their treatment course.

Conclusions: Most of the community still have poor knowledge regarding antibiotic use and its consequences such as allergy, and resistancy based on the knowledge questions has a total score $\leq 6$. Their attitude and behavior regarding antibiotic use are still poor which is also based on incompletion of the antibiotic treatment and irregular use.
\end{abstract}

Keywords: Antibiotic, attitude, behavior, knowledge

\section{Introduction}

Antibiotic is the most used drug in the treatment of infections caused by bacteria. High intensity in antibiotic prescription causes worldwide problem in antibiotic resistance. Besides mortality and morbidity, antibiotic resistance also causes economic and social effects. ${ }^{1}$ Resistance to antibiotic use causes pathogens cannot be cured by the same antibiotic and needs a different class of antibiotic, whereas development of new antibiotic drugs has slowed. Microorganism that is resistant in the first line drug, should use second line or third line antibiotic which inflicts financial loss to the patient because second line and third line antibiotic drug is expensive. $^{2}$

Furthermore, antibiotic misuse in the community is influenced by environmental and behavioral factors. Environmental factors included community preference for purchasing antibiotics, lack of health care infrastructures, lack of general practitioners and policy in regulating the antibiotic use. While behavioral factors are influenced by lack of information in antibiotic use and unawareness in antibiotic resistance. ${ }^{3}$ In Indonesia, ${ }^{4}$ antibiotic drugs can be purchased over the counter (OTC) or at the kiosk, whereas the Indonesian government regulation restricts antibiotic availability so that Antibiotic drugs can only be prescribed by doctors. The use of antibiotic drugs without prescription causes some problems in the community's behavior and attittude toward antibiotic use which are the use of inappropriate dosage and duration along with the use of left-over antibiotic. ${ }^{5}$ The aim of this study was to assess the level of knowledge, attitude and behavior regarding antibiotic use in community dwellings.

Correspondence: Rocci Jack Parse, Faculty of Medicine, Universitas Padjadjaran, Jalan Raya Bandung-Sumedang Km.21, Jatinangor, Sumedang, Indonesia, Phone: +6285263138760 Email: ciciho.roromo@gmail.com 


\section{Methods}

A cross sectional descriptive study was carried out during August 2013. The study population was the community that lived in one of the villages in Jatinangor, Sumedang, West Java, Indonesia, namely Cileles. The respondents were selected from 4 locations (RW 3, RW 5, RW 7 and RW 8) and 24 respondents were selected in each location using the rapid survey method. The inclusion criteria were people living in Cileles village and able to communicate with the Indonesian language. The exclusion criteria were people who did not want to participate in this study.

A structured questionnaire was developed by reviewing relevant literatures and questionnaires used previously in similar studies with several modification. ${ }^{6,7}$ The questionnaire comprised a total of 32 questions divided into four sections. The first section covered the participants demographic data such as age, address, sex, occupation, and education. The second section assessed community knowledge on the purpose of using antibiotics, antibiotic efficacy, safety and reasons leading to antibiotic resistance. The third section examined community attitude regarding antibiotic use, and the last section assessed community behavior regarding antibiotic use.

The questionnaire was validified in another village of Jatinagor, namely Hegarmanah village which had the same characteristics as Cileles village. Thirty respondents participated in this process. Each question was assigned as valid if the significance ( $p$-value) of the question was higher than 0.44 and reliable if the Cronbach's alpha value (a) was higher than 0.60 . The result was all the questions were valid and reliable.

Knowledge is the results from knowing something which occurs after having sensed the object; it could be a visual sense, tactile sense or smell. Attitude is a closed response against stimulus or object; it could be someone's perception or emotion. Behavior is the activity of someone or an open response against stimuli. ${ }^{8}$

Moreover, questions to determine the level of knowledge $(\mathrm{n}=12)$ were stated as "agree", "disagree" or "I do not know". Each correct answer would be given one point while the zero point was given to a wrong or "I do not know" answer. Whereas, questions on the participant's attitude were stated as "agree", "sometimes", "best not" and "disagree" with a range point from 1 to 4 . Questions on the participant's behavior were stated as "yes" and "no" questions.

Next, all data were coded, entered and analyzed using computer, for each correct answer, one point was given, whereas a wrong answer and "I do not know" answer did not affect the grade. Respondents with a total score of 7 or above were considered to have good knowledge, while those with a total score of 6 or below were considered to have poor knowledge. The analysis of answers of other questions was performed in descriptive quantitative statistics e.g. frequency and percentage. The respondents were informed about the study and were requested to complete an approval page. The identity of the respondents was kept confidential. This study was performed after it was approved by the Health Research Ethics Committee of the Faculty of Medicine, Universitas Padjadjaran, number 209/UN6.C2.1.2/KEPK/2013.

\section{Results}

The majority of respondents (35.4\%) were $36-45$ years old comprising $66.7 \%$ of female respondents and $47.9 \%$ of these respondents were housewives, while $40.6 \%$ of the respondents' education was elementary school (Table 1).

The level of knowledge about the use, effectiveness, resistance and safety of antibiotic was evaluated using statements . More than half of the respondents (80.2\%) knew that antibiotics were indicated to treat bacterial infections and $87.5 \%$ of respondents knew that antibiotics were indicated to treat swelling caused by infection. Additionally, $17.7 \%$ of respondents incorrectly believed that antibiotics could be used for viral infections, whereas, $39.6 \%$ of respondents believed that antibiotics could be used for common cold, $30.2 \%$ of respondents agreed that antibiotics were always used to treat fever and $50 \%$ of respondents agreed that antibiotics were always used to treat stomachache and diarrhea.

When asked about antibiotic resistance, the majority of respondents $(77.1 \%)$ knew that antibiotic resistance was caused by not following the clinical instructions, and less than one third of respondents $(22.9 \%)$ agreed that antibiotic effectiveness would not be affected by antibiotic misuse, $16.7 \%$ of respondents still believed that by changing the antibiotic brand would cause resistance, and $39.6 \%$ of respondents believed antibiotics would always be effective in the treatment of 


\section{Table 1 Subject Characteristics}

\begin{tabular}{|c|c|c|}
\hline & $\mathbf{n}$ & $\%$ \\
\hline \multicolumn{3}{|l|}{ Age(Years old) } \\
\hline $17-25$ & 6 & 6.2 \\
\hline $26-35$ & 20 & 20.8 \\
\hline $36-45$ & 34 & 35.4 \\
\hline $46-55$ & 17 & 17.7 \\
\hline $56-65$ & 10 & 10.4 \\
\hline$>65$ & 9 & 9.3 \\
\hline \multicolumn{3}{|l|}{ Occupation } \\
\hline Housewife & 46 & 47.9 \\
\hline Labor & 17 & 17.7 \\
\hline Private sector employees & 5 & 5.2 \\
\hline Students & 4 & 4.2 \\
\hline Civil servant & 7 & 7.3 \\
\hline Enterpreneur & 17 & 17.7 \\
\hline \multicolumn{3}{|l|}{ Education } \\
\hline Elementary school & 39 & 40.6 \\
\hline Junior high school & 23 & 24 \\
\hline Senior high school & 29 & 30.2 \\
\hline D1 & 1 & 1 \\
\hline D3 & 1 & 1 \\
\hline S1 & 3 & 3.1 \\
\hline \multicolumn{3}{|l|}{ Sex } \\
\hline Male & 32 & 33.3 \\
\hline Female & 64 & 66.7 \\
\hline
\end{tabular}

similar infections in the future. Respondent awareness about antibiotics possible adverse effect was quite high, $62.5 \%$ of respondents were aware of the harmful effect due to antibiotic allergy (Table 2).

By adding the total score of knowledge regarding antibiotic use, only $40.6 \%$ of the respondents had good knowledge and the majority of respondents $(59.4 \%)$ had poor knowledge regarding antibiotic use.

Furthermore, inconsistency in antibiotic use was also revealed in this study. Even though clinicians told the majority of respondents $(70.8 \%)$ how to use antibiotics, $45.3 \%$ of respondents did not take their antibiotics regularly. There was $5.2 \%$ of respondents who purchased antibiotic without consulting clinicians. Almost half of the respondents $(45.6 \%)$ agreed to stop antibiotic treatment after feeling better without consulting their physician first, while the majority of the participants were still unaware of the effect of antibiotic misuse, and $47 \%$ of the respondents agreed that they did not complete their antibiotic treatment (Table 3 ).

Incompleteness in antibiotic use was one of the major concern in this study, $12.5 \%$ of respondents who got a prescription for an antibiotic in the last course did not purchase all the antibiotics prescribed by the clinician, and $55.2 \%$ of respondents did not complete their treatment course. The reasons for this were various, 46 respondents were feeling better, 33 respondents who did not complete their treatment course threw the leftover antibiotic, and 3 respondents used the leftover antibiotic for another infection. More than half of the respondents (71.8\%) used antibiotics in 
Table 2 Knowledge of Respondent Regarding Antibiotic Use

\begin{tabular}{|c|c|c|c|}
\hline Questions & $\begin{array}{c}\text { Yes } \\
\text { n (\%) }\end{array}$ & $\begin{array}{c}\text { No } \\
\text { n (\%) }\end{array}$ & $\begin{array}{c}\text { I do not know } \\
\text { n (\%) }\end{array}$ \\
\hline \multicolumn{4}{|l|}{ Antimicrobial drug is used for: } \\
\hline Illness caused by bacteria ${ }^{1}$ & $77(80.2)$ & $3(3.1)$ & $16(16.7)$ \\
\hline Illness caused by viral ${ }^{2}$ & $17(17.7)$ & $57(59.4)$ & $22(22.9)$ \\
\hline Common cold ${ }^{2}$ & $38(39.6)$ & $52(54.2)$ & $6(6.2)$ \\
\hline Fever $^{2}$ & $29(30.2)$ & $56(58.3)$ & $11(11.5)$ \\
\hline Skin infection ${ }^{1}$ & $84(87.5)$ & $5(5.2)$ & $7(7.3)$ \\
\hline Stomach ache and diarrhea ${ }^{2}$ & $48(50)$ & $31(32.3)$ & $17(17.7)$ \\
\hline \multicolumn{4}{|l|}{ Antibiotic resistance due to: } \\
\hline Using antibiotic without clinical instruction ${ }^{1}$ & $74(77.1)$ & $10(10.4)$ & $12(12.5)$ \\
\hline Not completing the full course of antibiotic ${ }^{1}$ & $47(49)$ & $37(38.5)$ & $12(12.5)$ \\
\hline Using the same antibiotic with different brand ${ }^{2}$ & $16(16.7)$ & $54(56.2)$ & $26(27.1)$ \\
\hline $\begin{array}{l}\text { Using antibiotic when not necessary will increase } \\
\text { body immune }{ }^{2}\end{array}$ & $53(55.2)$ & $22(22.9)$ & $21(21.9)$ \\
\hline $\begin{array}{l}\text { An antibiotic will always be effective in the treatment } \\
\text { of the same infection in the future }\end{array}$ & $38(39.6)$ & $35(36.5)$ & $23(24)$ \\
\hline $\begin{array}{l}\text { Antibiotic might develop dangerous allergy in } \\
\text { sensitive person }{ }^{1}\end{array}$ & $60(62.5)$ & $21(21.9)$ & $15(15.6)$ \\
\hline
\end{tabular}

Note: ${ }^{1}$ Statements awarded respondents one point in scoring the level of knowledge upon agreement; ${ }^{2}$ Statements give respondent zero point in scoring the level of knowledge upon agreement

2013 so they still remembered their behavior regarding antibiotic use. While $84.2 \%$ of the respondents knew the kind of antibiotic prescribed so they knew which drug should be completed (Table 4).

\section{Discussion}

A majority of the respondents knew that antimicrobial is used against bacterial infections. A number of respondents still

Table 3 Attitude of Respondent Regarding Antibiotic Use

\begin{tabular}{lcccc}
\hline \multicolumn{1}{c}{ Attitude } & $\begin{array}{c}\text { Agree } \\
\mathbf{n ( \% )}\end{array}$ & $\begin{array}{c}\text { Sometimes } \\
\mathbf{n ( \% )}\end{array}$ & $\begin{array}{c}\text { Best not } \\
\mathbf{n ( \% )}\end{array}$ & $\begin{array}{c}\text { Disagree } \\
\mathbf{n ( \% )}\end{array}$ \\
\hline $\begin{array}{l}\text { Respondent use antibiotic without } \\
\text { clinical prescription when get illness }\end{array}$ & $14(14.6)$ & $24(25)$ & $9(9.4)$ & $49(51)$ \\
$\begin{array}{l}\text { Respondent follow clinical instruction } \\
\text { when prescribed antibiotic }\end{array}$ & $68(70.8)$ & $27(28.1)$ & $1(1)$ & $0(0)$ \\
$\begin{array}{l}\text { Respondent stop antibiotic use without } \\
\text { consulting their physician when the } \\
\text { symptoms reduced }\end{array}$ & $44(45.8)$ & $24(25)$ & $5(5.2)$ & $23(24)$ \\
$\begin{array}{l}\text { Respondent use antibiotic when get ill } \\
\text { and stop antibiotic use when feel better }\end{array}$ & $44(45.8)$ & $26(27.1)$ & $10(10.4)$ & $16(16.7)$ \\
$\begin{array}{l}\text { Respondent always complete their } \\
\text { antibiotic use when prescribed }\end{array}$ & $4(47.9)$ & $14(14.6)$ & $14(14.6)$ & $22(22.9)$ \\
\hline
\end{tabular}

Note: ${ }^{1}$ The respondent was given four points when answered "agree" statements, three points when answered "sometimes", two points when answered "best not", and one point when answered "disagree"; ${ }^{2}$ the respondent was given one point when answered "agree" statements, two points when answered "sometimes", three points when answered "best not", and four points when answered "disagree" 
Rocci Jack Parse, Eva Mardiana Hidayat, Bachti Alisjahbana: Knowledge, Attitude and Behavior Related to 275 Antibiotic Use in Community Dwellings

Table 4 Behavior of Respondent Regarding Antibiotic Use (1)

\section{Behavior}

n

Percent (\%)

1. Symptoms/illness

URTI

29

30.2

Diarrhea

9

9.4

Fever

22

22.9

Typhoid

9

9.4

Teeth problem

9.4

Etc

18.7

2. source of the drug

Puskesmas

Pharmacy

Drug store

OTC drug/kiosk

5.2

Etc

5

3. The clinician told respondent that antibiotics were prescribed

Yes

No

4. the prescriber told how to use antibiotics :

Yes

No

5. Knew which one is antibiotic drug

Yes

No

6. Duration in antibiotic use

3

Etc

7. did you buy all the drugs that has been prescribed:

yes

no

8. total duration in antibiotic use

$\begin{array}{lr}2 \text { days } & 6 \\ 3 \text { days } & 5 \\ 10 \text { days } & 1 \\ \text { Not change } & 84\end{array}$

$5 \quad 5.12$

1.04

$84 \quad 87.5$

9. complete last course of antibiotics

Yes

No 
Table 4 Behavior of Respondent Regarding Antibiotic Use (2)

\begin{tabular}{lcc}
\hline \multicolumn{1}{c}{ Behavior } & n & Percent (\%) \\
\hline $\begin{array}{l}\text { 10. reasons stated by respondent for not completing their last course } \\
\text { of antibiotics }\end{array}$ & & 47.9 \\
Felt better & 46 & 1 \\
Forgot & 1 & 3.1 \\
Side effect/antibiotics made me feel unwell & 3 & 3.1 \\
etc & 3 & 3.1 \\
11. respondent who kept the leftover antibiotic & 3 & 17.7 \\
use for another illness & 3 & 34.4 \\
just kept the antibiotic & 17 & 33 \\
\hline
\end{tabular}

believed that antibiotic was used against viral infection and some believed that antibiotic worked against both bacteria and virus. This confusion was due to some respondents believed that antibiotics could be used for all kinds of illness but actually antibiotic is only effective for bacteria and illnesses caused by bacteria. $^{2}$

Most of them were still unaware about antimicrobial resistance and considered that antibiotic resistance was not a problem since only $49 \%$ respondents answered that antibiotic resistance was due to incompleted antibiotic treatment. The fact is irrational use of antibiotic could lead to serious problems with the emergence and prevalence of resistant microbial strains, which have become a worldwide problem. ${ }^{9,10}$ Whereas this perception is wrong and causes antibiotic resistance is still high. ${ }^{2}$ Such wrong belief could cause wrong attitude and behavior against antimicrobial treatment.8 Besides resistance, antibiotic use without caution could lead to allergy and the most severe case is death. ${ }^{11}$ When asked about antibiotic allergy, 62.5\% respondents knew that antibiotic could lead to allergy in sensitive persons.

Remarkably in this study, the poor respondent knowledge about antibiotic was obvious since $59.4 \%$ of the participants total score illustrated $<6$ point, which was similar to a r study conducted at the Jordan university. ${ }^{6}$

The attitude and behavior of study participants with regards to antibiotic use and resistance was not good. More than half of the respondents did not finish the antibiotic treatment, and this attitude and behavior is similar to a study in India that has the same characteristics with Indonesia. ${ }^{3}$ The respondent's reason for this behaviour was they felt much better and one respondent forgot to took the antibiotic. This phenomenon became a bigger problem, time after time because people were still unaware of the effect of antibiotic, they did not know how antibiotic worked against microbacteria and thought that after the symptoms disappeared, they could stop taking antibiotic pills. Actually, the real effect of antibiotics is after the symptoms disappear because if the bacteria are not eradicated completely, the illness will return again with stronger bacteria. These strong bacteria could not be treated by the first line of antibiotic again or by an antibiotic that is resistant against it. So, the second line or third line of antibiotic should be used, even though the price of the antibiotic is much higher. The real problem is what should the physician do if the second or third line of antibiotic become resistant because the development of antibiotic drugs is still slow, and it needs much money and experimental studies. ${ }^{2}$

Fourteen percent of the respondents purchased antibiotics without a prescription at OTC or kiosk. This corresponded with Hadi et al. ${ }^{4}$ (2010) findings; this could occur because the regulations for antibiotic selling is not strong enough and there is no strong punishment for OTC or pharmacies selling the drug without prescription. ${ }^{1}$

This study has certain limitations that merit discussion. The sample of the study were majority female and housewives, this was due to handling the questionnaire to respondents during day time when presence of housewives was higher, while the husbands were gone to work. Moreover, a f future study should use a larger number of sample and longer period. 
Physician and health care workers should work together to explain that antimicrobial resistance is a serious problem worldwide and could be prevented by a simple action such as following the clinical instructions.

It can be concluded that the knowleedge, attitude and behaviour of the community are still poor regarding antibiotic use.

\section{References}

1. Sedyaningsih ER. Peraturan Menteri Kesehatan Republik Indonesia Nomor 2406/MENKES/PER/XII/2011. Jakarta. 2011.

2. Brunton L, Blumenthal D, Buxton I, Parker K. Goodman and Gilman's manual of pharmacology and therapeutics. 11th ed. United States of America. Mcgraw-Hill. 2007. p. 950-70.

3. Sahoo K C, Tamhankar A J, Johansson E, Lundborg C S. Antibiotic use, resistance development and environmental factors: a qualitative study among healthcare professionals in Orissa, India. BMC Public Health. 2010;1:1-10.

4. Hadi U, Broek Pvd, Kolopaking EP, Zairina N, Gardjito W, Gyssens IC. Cross-sectional study of availability and pharmaceutical quality of antibiotics requested with or without prescription (Over The Counter) in Surabaya, Indonesia. BMC Infectious Diseases. 2010; 10:203.

5. Foster SP, Boyd SM, Edgar TP. Patient behaviors and beliefs regarding antibiotic use. Alliance for the Prudent Use of Antibiotics 2010;1:1-3.

6. Shehadeh M, Suaifan G, Darwish M, Wazaify M, Zaru L, Alja'fari S. Knowledge, attitudes and behavior regarding antibiotics use and misuse among adults in the community of Jordan. A pilot study. Saudi Pharm J. 2012;20(2):125-33.

7. Buke C, Hosgor-Limoncu M, Ermertcan $S$, Ciceklioglu $M$, Tuncel $M$, Köse T, et al. Irrational use of antibiotics among university students. J Infect. 2005;51(2):135-9.

8. Notoatmodjo S. Promosi kesehatan dan ilmu perilaku. PT.RINEKA CIPTA: Jakarta. 2010.

9. Spellberg B, Bartlett JG, Gilbert DN. The Future of Antibiotics and Resistance. N Engl J Med. 2013;368(4):299-302.

10. Maryandi D. Gunakan Antibiotik Secara Tepat Untuk Mencegah Ke kebalan Kuman, Peringatan Hari Kesehatan Sedunia. Jakarta. 2011. p. 3.

11. Gruchalla RS, Pirmohamed M. Antibiotic allergy. N Engl J Med. 2006;354(6):601-9. 